\author{
KRISTÍN GUĐRÚN JÓNSDÓTTIR \\ HÁSKÓLI ÍsLANDS
}

\title{
Um Silvinu Ocampo
}

Á rið 1940 kom út bók í Argentínu sem átti eftir að njóta la literatura fantástica eða Úrvalsrit fantasíubókmennta. Í safninu eru sögur frá ólíkum tímabilum og heimshlutum, allt frá ævafornum kínverskum sögum til Edgars Allans Poe og Franz Kafka. Ritstjórar bókarinnar voru prír: pau Silvina Ocampo, eiginmaður hennar Adolfo Bioy Casares, og vinur peirra, Jorge Luis Borges. Öll höfðu pau brennandi áhuga á fantasíuforminu eins og átti eftir að koma fram í verkum peirra pótt með ólíkum hætti væri.

Silvina Ocampo fæddist árið 1903 í Búenos Aíres og var yngst sex dætra efnahjónanna Ramonu Aguierre og Manuels Silvinos Ocampo. Elst systranna var Victoria Ocampo, stofnandi og ritstjóri forlagsins Sur og samnefnds menningartímarits, sem var málpípa Sur-hópsins svonefnda, en ofangreint príeyki skipaði hluta pess. Margir telja ritið eitt mesta menningarrit sem hefur litið dagsins ljós í Rómönsku-Ameríku. Рað markaði að mörgu leyti stefnuna fyrir argentínskar nútímabókmenntir. Ung að árum nam Silvina teikningu og málaralist í París undir handleiðslu Fernands Léger og Giorgios de Chirico. Silvina átti löngum eftir að sameina mynd- og ritlist sína; hún myndskreytti meðal annars eigin bækur og annarra.

Rithöfundarferill hennar hófst árið 1937 pegar hún gaf út smásagnasafnið Viaje olvidado (Gleymt ferðalag). Ríflegur áratugur leið par til hún gaf út næsta smásagnasafn, Autobiografía de Irene (Sjálfsævisaga Irene, 1948). Í millitîđinni sendi hún frá sér prjár ljóðabækur: Enumeración de la patria (Upptalning föðurlands míns, 1942), Espacios métricos (Háttbundin rými, 1945) og Los sonetos del jardín (Sonnetturnar í garðinum, 1948). Allar hlutu pær 
góðar viðtökur og voru verðlaunaðar. Pess má geta að Borges var fyrstur til að lofa kveðskap Silvinu. Silvina skrifaði aðallega smásögur og ljóð en fékkst einnig við leikritaskrif og gaf út töluvert af barnabókum. Alls urðu smásagnasöfn hennar sjö talsins. Auk peirra fyrrnefndu sendi hún frá sér La furia (Heiftin,1959), Las invitadas (Boðsgestirnir, 1961) og Los días de la noche (Dagar næturinnar,1970). Sídustu smásagnasöfnin komu út nokkrum árum fyrir andlát hennar, $Y$ así sucesivamente (Og svo framvegis, 1987) og Cornelia frente al espejo (Cornelia andspænis speglinum,1988). Ocampo sinnti einnig pýðingum og sneri úr frönsku og ensku verkum eftir Charles Baudelaire, Paul Verlaine, Emily Dickinson, Edgar Allan Poe, Herman Melville og Emanuel Swedenborg. Hún gaf út nokkrar bækur í samstarfi við aðra. Auk Antología de la literatura fantástica sendi príeykið frá sér úrvalsrit argentínskra ljóða árið 1941. Pá skrifaði hún nokkur verk með eiginmanni sínum Bioy Casares, en einnig (fantasíu)höfundinum Juan Rodolfo Wilcock.

Smásögur Silvinu Ocampo spanna meira en fjóra áratugi. Ákveðna próun má merkja í smásagnagerð hennar, en segja má að almennt ríki í peim einkennilegt andrúmsloft, furðulegir atburðir gerast á ofur hversdagslegum stöðum við ofur hversdagslegar aðstæður, ekki hvað síst á borgaralegum heimilum yfirstéttarfólks. Ocampo teflir oft saman ráðandi stétt og valdalausri par sem pjónustufólk, börn eða fátækir eiga í hlut. Andstæður heimur fullorðinna og barna er algengt viðfangsefni í sögum hennar par sem grimmd og miskunnarleysi er allsráðandi. Hugmyndinni um einhvers konar umskipti, tvífara eða jafnvel endurholdgun er henni sérlega hugleikin. Fantasían eða furðan í verkum Ocampo gerist ævinlega í okkar kunnuglega og ápreifanlega heimi. Hvað petta varðar má segja að furðan í verkum hennar sé meira í ætt við Julio Cortázar en Bioy Casares og Borges par sem fantasían á sér stað í öðrum raunheimi, í hugarheimum eða pá í fyrndinni.

Silvina Ocampo var ekki mikið fyrir sviðsljósið. Hún forðaðist fjölmenni, einnig blaðamenn og vildi helst ekki láta taka af sér ljósmyndir. Að einhverju leyti var hún í skugga ekki aðeins Bioys Casares og Borgesar, heldur einnig elstu systur sinnar sem var miðjan í menningarlífi Argentínu pess tíma. Verk Silvinu fengu bó góðan hljómgrunn en féllu að einhverju leyti í gleymsku par til á 
KRISTÍN GUĐRÚN JÓNSDÓTTIR

níunda áratug sídustu aldar pegar pau fóru að vekja áhuga að nýju. Hún lést í fæðingarborg sinni, Búenos Aíres, árið 1993. 